\title{
Effects of nasopharyngeal microbiota in respiratory infections and allergies
}

Hyun Mi Kang, MD, Jin Han Kang, MD

Division of Pediatric Infectious Diseases, Departments of Pediatrics, College of Medicine, The Catholic University of Korea, Seoul, Korea

The human microbiome, which consists of a collective cluster of commensal, symbiotic, and pathogenic microorganisms living in the human body, plays a key role in host health and immunity. The human nasal cavity harbors commensal bacteria that suppress the colonization of opportunistic pathogens. However, dysbiosis of the nasal microbial community is associated with many diseases, such as acute respiratory infections including otitis media, sinusitis and bronchitis and allergic respiratory diseases including asthma. The nasopharyngeal acquisition of pneumococcus, which exists as a pathobiont in the nasal cavity, is the initial step in virtually all pneumococcal diseases. Although the factors influencing nasal colonization and elimination are not fully understood, the adhesion of opportunistic pathogens to nasopharyngeal mucosa receptors and the eliciting of immune responses in the host are implicated in addition to bacterial microbiota properties and colonization resistance dynamics. Probiotics or synbiotic interventions may show promising and effective roles in the adjunctive treatment of dysbiosis; however, more studies are needed to characterize how these interventions can be applied in clinical practice in the future.

Key words: Nasopharynx, Microbiota, Respiratory tract infections, Opportunistic infections, Pneumococcus

\section{Key message}

- The nasal microbiota varies with age and is shaped by various factors in healthy individuals.

- The pathological condition of the respiratory tract appears to be associated with reduced nasal microbiota biodiversity, while dysbiosis is involved in the pathophysiology of many respiratory diseases, including otitis, sinusitis, allergic diseases, and lower respiratory infections.

\section{Introduction}

The human microbiome, which consists of a collective cluster of commensal, symbiotic, and pathogenic microorganisms living on the human body, plays a key role in host health and immunity. ${ }^{1)}$ The human nasal cavity harbors commensal bacteria that suppress the colonization of opportunistic pathogens. However, when a microbial community becomes dysfunctional or imbalanced, opportunistic pathogens in the bacterial microbiome of the nasopharyngeal or nasal sinus cavity can spread to adjacent regions of the respiratory tract and become involved in the development of diseases such as acute respiratory infections including otitis media (OM), sinusitis, and bronchitis and allergic respiratory diseases including asthma. ${ }^{2,3)}$ In fact, many environmental factors modulate the composition of the nasal microbiome, ${ }^{4,5)}$ which is not constant throughout life; rather, it is dependent on the body's habitat and host health status. ${ }^{6}$ From this aspect, we review the factors influencing changes in the nasal microbiota, causalities with disease development, and immune alterations.

\section{Nasal microbiota influencing factors and health}

Many studies recently reported on the complexity of the nasopharyngeal microbiota in children and adults, which undergo significant changes upon exposure to disease, environmental hazards, and antimicrobial agents or vaccinations. In addition, delivery type, feeding or dietary habituation, smoking, lifestyle, pollution, and hygiene are well known influencing factors that modulate the nasal microbiota. These differences are related to genetic background variables and socioeconomic conditions such as housing, health care, poor hygiene, family size, overcrowded living conditions, day care contact, and number of siblings. In fact, newborns delivered by vaginal versus cesarean delivery are exposed to different microbiota, ${ }^{7)}$ and early postnatal bacterial colonization of the upper airways is significantly affected by birth season. ${ }^{8)}$ A recent study reported that the nasal microbiota among dairy farmers is more complex than their oral microbiota, which protects against infections and competes with Staphylococcus aureus colonization (Table 1).9)

The nasal microbiota consists of various microbial commu-

\footnotetext{
Corresponding author: Jin Han Kang, MD, Department of Pediatrics, Seoul St. Mary's Hospital, College of Medicine, The Catholic University of Korea, 222 Banpo-daero, Seocho-gu, Seoul 06591, Korea 
Table 1. Summary of nasopharyngeal microbiome composition by age, factors that affect the composition, and associated diseases in children

\begin{tabular}{|c|c|c|c|}
\hline Age & $\begin{array}{l}\text { Factors affecting } \\
\text { the nasal microbiome }\end{array}$ & Microbiome composition & Association with diseases \\
\hline Birth & $\begin{array}{l}\text { Delivery mode } \\
\text { - infant's nasopharyngeal } \\
\text { microbiome resembles } \\
\text { maternal vaginal or skin } \\
\text { microbiome }\end{array}$ & $\begin{array}{l}\text { Moraxella } \\
\text { Staphylococcus } \\
\text { Streptococcus } \\
\text { Haemophilus } \\
\text { Dolosigranulum } \\
\text { Corynebacterium } \\
\text { (Usually, } 1 \text { or } 2 \text { dominate the nares) }^{65,85,86)}\end{array}$ & $\begin{array}{l}\text { - Neonatal airway colonization with } S \text {. pneumoniae, } H \text {. } \\
\text { influenza, or } M \text {. catarrhalis is associated with increased } \\
\text { risk of pneumonia and bronchiolitis in early life } \\
\text { independently of asthma }\end{array}$ \\
\hline 1.5 months & $\begin{array}{l}\text { Feeding mehod } \\
\text { Genetics }^{7)} \\
\text { Siblings } \\
\text { Environmental factors }^{4,5)} \\
\text { Cigarette smoke }^{7)} \\
\text { Infection history }^{2,3)} \\
\text { Hygiene }^{7)}\end{array}$ & $\begin{array}{l}\text { Staphylococcus, Moraxella, Streptococcus, } \\
\text { Corynebacterium, and/or Dolosigranulum }{ }^{83)} \\
\text { - Breastfeeding: Dolosigranulum/Coryne- } \\
\text { bacterium dominant profiles }{ }^{84)} \\
\text { - Formula-feeding: increase in S. aureus } \\
\text { profiles }^{83,84,87)}\end{array}$ & $\begin{array}{l}\text { - Dolosigranulum/Corynebacterium dominant profiles: } \\
\text { Protective against respiratory infections } \\
\text { Moraxella spp.-dominated profiles: less likely to suffer } \\
\text { from upper respiratory infections }{ }^{65)} \\
\text { - H. influenza, S. pneumoniae, Moraxella catarrhalis: } \\
\text { associated with wheezing in one-month-old infants }\end{array}$ \\
\hline $\begin{array}{l}\text { Beyond } 1.5 \\
\text { months }\end{array}$ & Antibiotics ${ }^{7)}$ & $\begin{array}{l}\text { - Haemophilus-dominated clusters emerge } \\
\text { and Staphylococcus-dominated profiles } \\
\text { disappear } \\
\text { - Corynebacterium/Dolosigranulum patterns } \\
\text { replaced by Moraxella/Dolosigranulum- } \\
\text { dominated clusters } \\
\text { - Dolosigranulum and Moraxella combined } \\
\text { with Corynebacterium form a more stable } \\
\text { microbiome compared to Streptococcus } \\
\text { and Haemophilus-dominant profiles }\end{array}$ & $\begin{array}{l}\text { - Nasopharyngeal Streptococcus: strong predictor for } \\
\text { asthma in approximately 2-month-old children }{ }^{65,83,88)} \\
\text { - Moraxella, Staphylococcus, Corynebacterium, Haemo- } \\
\text { philus, Fusobacterium, Prevotella, and Dolosigranulum } \\
\text { were dominant in asthmatic children }{ }^{68)} \\
\text { H. influenza and } S \text {. pneumoniae were associated with } \\
\text { respiratory viruses and an elevated risk of bronchiolitis } \\
\text { in early life } \\
\text { - S1,83,90-92) } \\
\text { influenzae and } S \text {. pyogenes has been associated with } \\
\text { increased risk of death in adults and children infected } \\
\text { with influenza }\end{array}$ \\
\hline
\end{tabular}

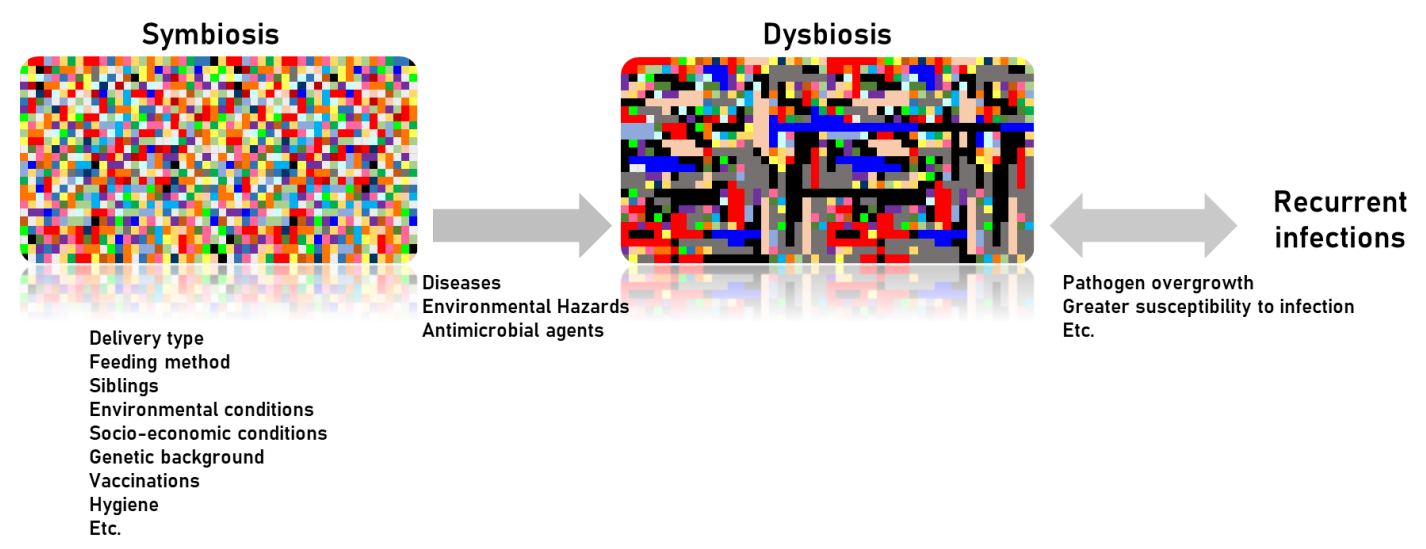

Fig. 1. Diversity of the microbiome in symbiosis and dysbiosis. Delivery type, environmental conditions, socioeconomic conditions, and genetic background are factors that shape the nasopharyngeal microbiome of children. However, diseases such as allergic rhinitis, environmental hazards, and antibiotic usage can lead to dysbiosis, resulting in pathogen overgrowth, which may lead to recurrent infections.

nities, including many different genera of aerobic and anaerobic microorganisms. Dysbiosis of the nasal microbiota may lead to pathogenic overgrowth and greater susceptibility to infection, as has been observed in the gastrointestinal tract and lower airways. In unhealthy situations, many respiratory pathogens, including resistant strains, may be reserved as nasopharyngeal microbiota and serve as a source for the transfer of antimicrobial-resistant genes from non-pathogenic to pathogenic bacteria. ${ }^{10)}$ Therefore, the abundance and diversity of nasal microbiota are prognostic factors of good health (Fig. 1). ${ }^{711-13)}$
In conclusion, the factors influencing nasal colonization and elimination are not fully understood, but adhesion to nasopharyngeal mucosa receptors and immune responses are implicated in addition to the properties of the nasopharyngeal bacterial microbiota and the dynamics of colonization resistance. Overall, potential pathogens are more likely to colonize the nasopharynx of children with recurrent respiratory infections, including $\mathrm{OM}$, due to their impaired local immunity and repeated exposure to respiratory pathogens as well as adults with chronic respiratory tract disease, who have higher carriage rates (Table 2). ${ }^{14)}$ 


\section{Nasopharyngeal microbiota with acute respiratory infections: focus on immune defense correlations}

The early postnatal bacterial colonization of the upper airways is significantly affected by birth season, emphasizing a future need to focus on the seasonality aspect in models of the impact of early dynamic changes in airway bacterial communities in relation to later disease development. Nasopharyngeal colonization occurs early in life and is consistently present thereafter, although bacterial species and strains are transient, particularly with antibiotic use and pneumococcal vaccine routines. ${ }^{15-17)}$

The most important role of nasal mucosal immunity is to defend the adjacent respiratory organs against invading pathogens while continuing to maintain symbiotic relationships between extensive microbiota and the host. ${ }^{18)}$ The main bacterial nasopharyngeal microbiota of OM, Streptococcus pneumoniae, nontypeable Haemophilus influenzae, and Moraxella catarrhalis are most likely to engage in a virulence shift. ${ }^{19)}$ Such influences are multifactorial and include microbial interactions, microbial carriage load, mucosal integrity, demographic and environmental factors, and host immunity. ${ }^{20,21)}$ Moreover, lymphocyte expansion and maturation into effector lineages is influenced by antigen exposure and dose, whereby high-dose continual antigen exposure supports the differentiation and expansion of

Table 2. Alterations in nasopharyngeal microbiota versus healthy individuals ${ }^{7)}$

\begin{tabular}{|c|c|c|}
\hline Pathogen or disease & Increase & Decrease \\
\hline Influenza A virus & $\begin{array}{l}\text { S. pneumoniae }{ }^{26)} \\
\text { S. aureus }{ }^{26,27)} \\
\text { Phyllobacterium spp. }{ }^{27)} \\
\text { Moraxella spp. } \\
\text { Corynebacterium spp }{ }^{27)} \\
\text { Dolosigranulum spp. }\end{array}$ & Pseudomonas spp. ${ }^{95)}$ \\
\hline Rhinovirus-A & $\begin{array}{l}\text { S. pneumoniae }{ }^{28,59)} \\
\text { Haemophilus spp. }^{30)}\end{array}$ & \\
\hline Rhinovirus-C & $\begin{array}{l}\text { S. pneumoniae } e^{28,59)} \\
\text { Moraxella spp. }{ }^{30)}\end{array}$ & \\
\hline Adenovirus & S. pneumoniae ${ }^{59)}$ & \\
\hline RSV & Haemophilus spp. ${ }^{30)}$ & \\
\hline OM & $\begin{array}{l}\text { Moraxella spp. }{ }^{3074)} \\
\text { S. pneumonia }{ }^{74,96,97)} \\
\text { Pasteurella spp. }{ }^{97)} \\
\text { Haemophilus spp. }{ }^{74,97)} \\
\text { Actinomyces spp. }{ }^{97)} \\
\text { Rothia spp. } .^{97)} \\
\text { Neisseria spp. }{ }^{97)} \\
\text { Veillonella spp. }{ }^{97)}\end{array}$ & 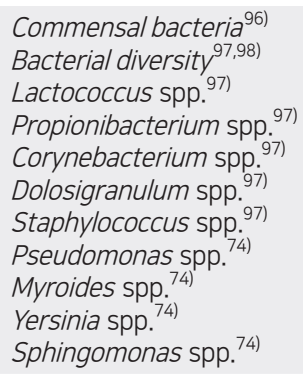 \\
\hline Recurrent OM & $\begin{array}{l}\text { Gemella spp. }{ }^{98)} \\
\text { Neisseria spp. }{ }^{98)}\end{array}$ & $\begin{array}{l}\text { Corynebacterium spp. }{ }^{98)} \\
\text { Dolosigranulum spp. }{ }^{98)}\end{array}$ \\
\hline Chronic rhinosinusitis & $\begin{array}{l}\text { Coagulase-negative } \\
\text { Staphylococcus } \\
\text { P. aeruginosa } \\
\text { S. aureus } \\
\text { 99-101) }\end{array}$ & Bacterial diversity ${ }^{4)}$ \\
\hline
\end{tabular}

RSV, respiratory syncytial virus; OM, otitis media.
Treg lymphocytes. ${ }^{22-24)}$

One study suggested that circulating regulatory T lymphocytes may contribute to a host's tolerance of nasopharyngeal colonization and the potential development of chronic OM. ${ }^{22}$ From this aspect, it is very important to determine the relationships between these factors and host immune responses to gain an increased understanding of its pathogenesis.

The host immune response against invading respiratory viruses can provoke protective immunity in the respiratory microbiome, including the nasal microbiome. ${ }^{25)}$ An influenza A virus infection can modify the community structure of the respiratory microbiome by increasing the number of pathogenic bacteria. In fact, influenza A infections showed increased nasal carriage of $S$. pneumoniae and $S$. aureus in adults and showed nasal microbiota differences between healthy persons and influenza A-infected patients. ${ }^{26,27)}$ Other viruses such as adenovirus and rhinovirus can increase the colonization density of S. pneumoniae in the nasal and respiratory tract, continuously increasing the risk of pneumococcal infection. ${ }^{28)}$ Elevated $H$. influenzae or Moraxella nasal carriages were observed after several viral infections such as respiratory syncytial virus or rhinovirus in infants. ${ }^{29-31)}$

In conclusion, nasal microbiota dysbiosis is associated with respiratory viral pathogen invasion, escaping the host immune system and leading to respiratory diseases.

\section{Nasopharyngeal microbiota with OM}

Acute $\mathrm{OM}(\mathrm{AOM})$ is among the most common pediatric infectious diseases. The mechanism of bacterial AOM development is well known; a respiratory viral infection disrupts the mucociliary system, impairing the host's primary mechanical defense against bacterial invasion, continuously leading to reduced middle ear pressure and forcing mucus, nasopharyngeal secretions, and bacteria colonies from the nasopharynx into the middle ear. ${ }^{31,32)}$ Although the disease is primarily considered a bacterial infection, it is also well known that viral upper respiratory tract infections (URIs) predispose children to $\mathrm{AOM}$ and viruses alone can cause AOM. ${ }^{33)}$ The nasopharyngeal bacterial microbiota in healthy individuals differs from nasopharyngeal colonization in individuals with URIs or AOM..$^{34,35)}$ Children concurrently colonized with S. pneumoniae, nontypable $H$. influenzae, and M. catarrhalis are at higher risk of developing AOM than children without pathogenic bacteria. Children have more bacterial types and higher bacterial colony counts in the nasopharynx during URIs than during a healthy period. However, the majority of causative pathogens associated with AOM were newly acquired pathogens, not those found during the healthy period. ${ }^{35)}$ Finally, the effective prevention of AOM must include the prevention of viral URIs and the prevention and/or elimination of nasopharyngeal colonization with pathogenic bacteria. ${ }^{36}$ ) However, to effectively prevent AOM, more studies are required to better understand how these interventions affect bacterial and viral interactions in the 
pathogenesis of viral AOM.

$\mathrm{OM}$ with effusion (OME) is the most common cause of hearing alterations in childhood. ${ }^{37)}$ S. pneumoniae, H. influenzae, and M. catarrhalis are the most common pathogens of OME based on classical culture approaches. With the recent advancement of culture-independent techniques such as 16S rRNA pyrosequencing, previously unknown bacterial communities have now been identified within the middle ear. ${ }^{38)}$ In fact, Alloiococcus, Haemophilus, Staphylococcus, Corynebacterium, Streptococcus, and Moraxella were proven as important pathogens in OME development using both traditional culture, culture-independent polymerase chain reaction, and $16 \mathrm{~S}$ pyrosequencing techniques. 38-41) In addition, the adenoid microenvironment does not correlate with the middle ear microenvironment, and it has been confirmed that OME is not a sterile condition and casts doubt on the commonly held belief that the adenoid pad serves as a bacterial reservoir for OME, while the microenvironment of the middle ear itself may play a greater role in influencing the constitution of the microbial communities within them rather than bacteria from the nasopharynx. Moreover, differences between the local microbiota of the adenoid and the middle ear strongly suggest that the microenvironment of the middle ear plays a greater role in the composition of the microbiota than the potential bacterial seeding from the adenoid pad to the middle ear in children with OME. ${ }^{42)}$ However, further studies of the causal relationship between the microbiome of the middle ear and OME pathogenesis are needed (Table 2).

\section{Nasopharyngeal microbiota with sinusitis}

Acute and chronic rhinosinusitis are the most frequent complications in children with complicated diseases. Therefore, extensive studies have been performed. Among them, a number have clarified various microbiological aspects of rhinosinusitis, including its epidemiology and the role of bacterial biofilm producers. Studies of the microbiota of the nasosinus in healthy children and adults were recently conducted. However, no precise bacterial and/or viral etiology has yet been established and knowledge remains limited. A few studies suggested that microbiotal diversity increases significantly with age. Moreover, the ecological changes in the nasopharyngeal and nasal cavity sites may influence the development of adenoid hypertrophy or result from hypertrophy in healthy controls and patients with sinusitis. $^{43,44)}$

Many researchers consider bacteria with or without biofilm "social organisms" that form the so-called microbiota. Sinonasal microbiota can modulate the course of both acute and chronic rhinosinusitis. As the composition, distribution, and abundance of microbiota in the nasosinus cavity impact mucosal health and can influence pathogenic growth and function, a greater understanding of the host-microbiome constituents and relationships may encourage the development of new treatments for acute or chronic rhinosinusitis. ${ }^{11)}$ The concentration, uniformity, and type/number of strains of sinonasal microbiota may vary among sites. The relative and total microorganism counts can also be affected by various factors. ${ }^{45,46)}$ In fact, the presence and percentage of microorganisms can be influenced by previous antimicrobial treatments, vaccinations, the presence of normal flora capable of interfering with pathogenic growth, geography, and site, as the maxillary, ethmoid, and frontal sinuses show different etiologies. ${ }^{47)}$ Therefore, it is difficult to use such data when deciding the choice of antibiotic treatment for controlling sinusitis.

The formation of biofilm in rhinosinusitis may play a significant role in its pathogenesis and persistence. Biofilm has a number of advantages in terms of bacterial survival, and their perpetuation can create a certain degree of instability in hostbacterial interactions. A number of aerobes and anaerobes are capable of producing biofilm, which differs depending on the microorganism and stimulates various inflammatory molecules during acute or chronic rhinosinusitis. The most negative features of biofilm are their high degree of resistance to antibiotics and host immune mechanisms, as they are less susceptible to opsonization and phagocytosis. ${ }^{48)}$

In conclusion, the relationship between microbiota and sinonasal diseases has been well characterized, but further studies are necessary to establish its implications for the bacterial network under pathological conditions.

\section{Nasopharyngeal microbiota with pneumococcal infections}

S. pneumoniae, also known as pneumococcus, is among the deadliest pathogens in humans and one of the most dominant causes of sepsis, pneumonia, OM, and sinusitis. Pneumococcus is colonized at some point in nearly all humans during childhood at various durations and frequencies by age. ${ }^{49)}$ However, most individuals do not develop pneumococcal diseases; rather, a perfect balance is maintained between the host, pneumococcus, and microbiota. The disruption of this balance alters the existence of pneumococcus as a commensal pathogen and is, therefore, called a pathobiont.

The nasopharyngeal acquisition of pneumococcus is the first step of virtually all pneumococcal diseases, ${ }^{50)}$ while children with no bacteria in the nasopharynx are considered at low risk of developing disease. $\left.{ }^{36}\right)$ The following 2 important questions arise: (1) can pneumococcal vaccines prevent colonization, which subsequently prevents pneumococcal diseases; and (2) which factors influence the change of pneumococcus from a simple colonizer to a virulent pathogen?

The concern of eliminating a population of bacteria from its niche would be replacing the void with other pathogens that could cause similar but more severe diseases. ${ }^{51)}$ There are currently 3 licensed pneumococcal vaccines in Korea: the 10-valent pneumococcal conjugate vaccine (PCV10), the 13valent pneumococcal conjugate vaccine (PCV13), and the 
23-valent pneumococcal polysaccharide vaccine (PPSV23). After the introduction of these vaccines, there have been many studies on the nasopharyngeal carriage rate, serotypes of $S$. pneumoniae, and antimicrobial susceptibilities. These studies show that although conjugate vaccines have been immensely successful at reducing and eliminating diseases caused by vaccine serotypes, the colonization rate has not changed; rather, there has been a replacement in the colonization of nasopharyngeal pneumococcal serotypes into nonvaccine types that show nonsusceptibility to penicillin and erythromycin. ${ }^{51-55)}$

The cocolonization and polymicrobial interaction of pneumococcus with other respiratory colonizers, mainly non-typeable $H$. influenzae and M. catarrhalis cause different risks regarding the development of $\mathrm{OM}^{36}{ }^{36}$ In fact, in children who have concomitant nontypeable $H$. influenzae and S. pneumoniae in the nasopharynx, many pneumococcal serotypes demonstrate lower rates of progression to OM, and nontypeable $H$. influ. enzae is likely the cause in up to $75 \%$ of cases. ${ }^{56,57)}$ An animal model suggested that increased neutrophil recruitment and promotion of pneumococcal clearance, which then diminishes the ability of pneumococcus to progress to disease, is the primary mechanism. ${ }^{58)}$ Regarding the cocolonization by S. pneumoniae and $S$. aureus, no negative interaction was observed. $\left.{ }^{26}\right)$

The coinfection with some respiratory viruses increases the rate of colonization with pneumococcus and causes high pneumococcal colonization densities, consequently having significant associations with invasive pneumococcal pneumonia. ${ }^{59)}$ There are also many studies of the synergistic effect of concomitant pneumococcal-influenza infections. Influenza virusinduced polymorphonuclear neutrophil dysfunction is a key component of influenza virus-induced secondary pneumococcal diseases; although the role of polymorphonuclear neutrophils is unclear, the data indicate that neutrophils may play both protective and damaging roles in response to pneumococcal infections (Table 2) ${ }^{60)}$

Serotype is an important factor that determines the progression from pneumococcal colonization to disease, and some serotypes have a higher potential to cause invasive disease than others. However, unlike those causing invasive diseases, little difference was noted among serotypes in their ability to ascend from the nasopharynx to the middle ear and subsequently cause mucosal diseases ${ }^{61,62)}$ although there can be a difference of up to 100 -fold in the degree. ${ }^{63)}$ Altogether, this explains how conjugate vaccines do not reduce the prevalence of pneumococcal nasal carriage but decrease the incidence of invasive pneumococcal diseases and impact the incidence of acute and complex OM.

In conclusion, the current vaccines effectively reduce pneumococcal diseases caused by vaccine serotypes, especially invasive diseases. However, nonvaccine serotypes are replacing the niche, and further studies are needed to determine the overall burden of replaced serotypes on pneumococcal diseases, especially in mucosal diseases such as AOM. To the best of our knowledge, cocolonization and polymicrobial interaction of pneumococcus with other respiratory colonizers, coinfection with respiratory viruses, and serotypes are some factors that determine whether pneumococci remains colonizers or become pathogens.

\section{Nasopharyngeal microbiota with allergic rhinitis and asthma}

Many studies have suggested that the nasal microbiome may play an important role in the modulation of localized immune responses and development of respiratory allergic diseases such as allergic rhinitis and asthma., ${ }^{3,64-66)}$ In fact, the nasal microbiota before and during pollen seasons show a significant increase in bacterial biodiversity in the middle meatus in patients with seasonal allergic rhinitis compared to healthy controls and a correlation between an increase in symptoms and nasal eosinophil counts in allergic rhinitis patients. ${ }^{66)}$ However, the data remain limited. Further studies are needed to fully understand the role of nasal microbiome dysbiosis in allergic rhinitis. Although the correlation between nasal microbiota and asthma is poorly defined, several recent studies have demonstrated that the nasal microbiota plays a significant role in asthma onset, development, and severity. ${ }^{67-69)}$ One study reported on the nasopharyngeal microbiome during the first year of life and found that the nasopharyngeal microbiome was a determining factor of future asthma development and the severity of its accompanying inflammatory symptoms, with early asymptomatic colonization with Streptococcus in particular being a strong predictor of the future risk of asthma development. ${ }^{65)}$ Another study reported that the composition and structure of the nasal microbiota of children and adolescents with asthma were significantly different from those of healthy controls and varied among different asthma phenotypic clusters. $^{70)}$ In asthmatic children. the nasal microbiome was dominated by Moraxella, Staphylococcus, Corynebacterium, Haemophilus, Fusobacterium, Prevotella, and Dolosigranulum. ${ }^{68)}$ Furthermore, asymptomatic colonization in neonates with the common respiratory tract pathogens $H$. influenzae, $M$. catarrhalis, and S. pneumoniae has been shown to confer a higher risk of subsequent lung diseases, including childhood asthma. ${ }^{32,33,71)}$ One study reported that nasopharyngeal Borde. tella pertussis colonizing infections are harmless but that subclinical B. pertussis colonization is an important cause of asthma and allergic sensitization diseases. ${ }^{72)}$ On the other hand, Bacteroidetes and Proteobacteria, Prevotella buccalis, and Gardnerella vaginalis were abundant in adult asthma patients, and P. buccalis, G. vaginalis, Dialister invisus, and Alkanindiges hongkongensis species were differentially abundant depending on asthma activity. ${ }^{73)}$ However, future studies are needed of nasal microbiome dysbiosis in asthma patients. 


\section{Novel approaches to controlling nasopharyngeal microbiota}

Although antibiotics and vaccines can partially reduce or eliminate nasal pathogens, they cannot correct nasal microbiota dysbiosis. Human pathogens, which are also part of the normal microbiota, complicate the eradication paradigm. There have been recent promising developments in the use of probiotics or probiotics with prebiotics as adjuvant treatments for controlling nasal dysbiosis. Several studies have reported that some probiotics such as Lactobacillus acidophilus, Lactobacillus paracasei, and Lactobacillus rhamnosus GG improve symptoms of allergic rhinitis by altering immunologic responses. ${ }^{74-76)}$ In 2 separate trials, newborns who were administered synbiotics had a significantly lower incidence of respiratory tract infections (especially rhinoviral infections) than those administered placebo. ${ }^{77,78)}$ Probiotics such as Streptococcus salivarius $24 \mathrm{SMBc}$ and Streptococcus oralis 89a may reduce S. aureus as a result of limiting the overgrowth of potential pathogens. ${ }^{79)}$ The intranasal administration of Bacillus subtilis vaccine in humans to enhance the immunity of human nasal mucosa to respiratory diseases could be attempted in the future (Table 3). ${ }^{80}$

\section{Conclusions}

The nasal microbiota varies with age and is shaped by various influencing factors in healthy individuals. A pathological condition of the respiratory tract appears to be associated with a reduction in nasal microbiota biodiversity; a similar feature was also shown in other sites such as the gastrointestinal tract.
Nasopharyngeal microbiota dysbiosis is involved in the pathophysiology of many respiratory diseases, including OM, sinusitis, allergic diseases, and lower respiratory tract infections. In addition, recent studies suggested that the profile of nasal microbiota influences immune responses and has the potential to be used as a prognostic tool for diseases in clinical practice. Therefore, instead of previous classical culture approaches and high-cost methods, the use of widely available low-cost methodologies should be considered to enable the practical clinical use of the nasal microbiota profile. For instance, various simple polymerase chain reaction methods, such as broadrange polymerase chain reaction that uses the $16 \mathrm{~S}$ rRNA to identify taxonomy of bacterial species, are relatively cheap, can only identify a relatively small array of genes, and are useful in identifying disease biomarkers and prognostic factors in clinical care.

Of note, current data in the literature were acquired from cross-sectional cohort studies involving diseased and healthy populations; therefore, longitudinal cohort studies are required. In addition, we should consider the importance of a combined classification model including bacterial microbiome, viral microbiome, and external factors such as antibiotic use and breastfeeding in predicting clinical disease status. Several studies suggested that probiotic or synbiotic interventions may show promising effective roles in the adjunctive treatment of perennial allergic rhinitis and seasonal allergic rhinitis, with improvements occurring through species-specific interactions and immunological modulatory responses (Table 3). However, data are limited and future studies are needed to characterize how these interventions can be applied in clinical practice.

Table 3. Role of probiotics in respiratory tract infections, chronic rhinosinusitis, and allergic rhinitis

\begin{tabular}{|c|c|c|}
\hline Type of disease & For use & Against use \\
\hline \multirow[t]{4}{*}{$\begin{array}{l}\text { Respiratory tract } \\
\text { infections }\end{array}$} & $\begin{array}{l}\text { - Artificial inoculation of Corynebacterium pseudodiphtheriticum into } \\
\text { the nasal cavity appears to eradicate Staphylococcus aureus nasal } \\
\text { colonization }{ }^{13,102,103)}\end{array}$ & \\
\hline & $\begin{array}{l}\text { - Streptococcus salivarius } 24 \mathrm{SMBc} \text { and Streptococcus oralis } 89 a \\
\text { significant decreased S. aureus abundance and an increase in the } \\
\text { total number of beneficial microorganisms }\end{array}$ & \\
\hline & $\begin{array}{l}\text { - Newborns administered prebiotics and probiotics had a significantly } \\
\text { lower incidence of respiratory tract infections }{ }^{77,78)}\end{array}$ & \\
\hline & $\begin{array}{l}\text { - Newborns given Lactobacillus plantarum had significant reductions } \\
\text { in the incidence of respiratory tract infections }{ }^{78)}\end{array}$ & \\
\hline \multirow[t]{2}{*}{$\begin{array}{l}\text { Chronic } \\
\text { rhinosinusitis }\end{array}$} & & $\begin{array}{l}\text { - No significant clinical improvements in sinonasal quality- } \\
\text { of-life scores with oral administration of a preparation } \\
\text { containing Lactobacillus rhamnosus }\end{array}$ \\
\hline & & $\begin{array}{l}\text { - Intranasal Lactobacillus spp. and Bifidobacterium spp., did } \\
\text { not produce any changes in symptoms, inflammatory } \\
\text { biomarkers in nasal lavage fluids, or commensal bacteria } \\
\text { of the nasal cavity }\end{array}$ \\
\hline \multirow[t]{3}{*}{ Allergic rhinitis } & $\begin{array}{l}\text { Administration of } L \text {. acidophilus significantly improved nasal } \\
\text { symptom scores in participants with perennial allergic rhinitis }\end{array}$ & \\
\hline & $\begin{array}{l}\text { Improvement in pediatric rhinoconjunctivitis quality-of-life scores } \\
\text { and a significant improvement in nasal itching and sneezing scores } \\
\text { in children treated with Lactobacillus paracasei }\end{array}$ & \\
\hline & $\begin{array}{l}\text { Children treated with Lactobacillus rhamnosus GG had better } \\
\text { immunologic response to immunotherapy }{ }^{76)}\end{array}$ & \\
\hline
\end{tabular}




\section{Footnotes}

Conflicts of interest: No potential conflict of interest relevant to this article was reported.

ORCID:

Hyun Mi Kang @ https://orcid.org/0000-0003-0513-8407

Jin Han Kang (1) https://orcid.org/0000-0003-1610-6742

\section{References}

1. Abt MC, Osborne LC, Monticelli LA, Doering TA, Alenghat T, Sonnenberg GF, et al. Commensal bacteria calibrate the activation threshold of innate antiviral immunity. Immunity 2012;37:158-70.

2. Esposito S, Principi N. Impact of nasopharyngeal microbiota on the development of respiratory tract diseases. Eur J Clin Microbiol Infect Dis 2018;37:1-7.

3. Huang YJ. Nasopharyngeal microbiota: gatekeepers or fortune tellers of susceptibility to respiratory tract infections? Am J Respir Crit Care Med 2017;196:1504-5.

4. Rawls M, Ellis AK. The microbiome of the nose. Ann Allergy Asthma Immunol 2019;122:17-24.

5. Arrieta MC, Stiemsma LT, Amenyogbe N, Brown EM, Finlay B. The intestinal microbiome in early life: health and disease. Front Immunol 2014;5:427.

6. Thomas S, Izard J, Walsh E, Batich K, Chongsathidkiet P, Clarke G, et al. The host microbiome regulates and maintains human health: a primer and perspective for non-microbiologists. Cancer Res 2017;77:1783-812.

7. Dimitri-Pinheiro S, Soares R, Barata P. The microbiome of the nose-friend or foe? Allergy Rhinol (Providence) 2020;11:2152656720911605.

8. Schoos AM, Kragh M, Ahrens P, Kuhn KG, Rasmussen MA, Chawes BL, et al. Season of birth impacts the neonatal nasopharyngeal microbiota. Children (Basel) 2020;7:45.

9. Shukla SK, Ye Z, Sandberg S, Reyes I, Fritsche TR, Keifer M. The nasal microbiota of dairy farmers is more complex than oral microbiota, reflects occupational exposure, and provides competition for staphylococci. PLoS One 2017;12:e0183898.

10. Manenzhe RI, Dube FS, Wright M, Lennard K, Zar HJ, Mounaud S, et al. Longitudinal changes in the nasopharyngeal resistome of South African infants using shotgun metagenomic sequencing. PLoS One 2020; $15: \mathrm{e} 0231887$.

11. Lee JT, Frank DN, Ramakrishnan V. Microbiome of the paranasal sinuses: update and literature review. Am J Rhinol Allergy 2016;30:3-16.

12. Mika M, Mack I, Korten I, Qi W, Aebi S, Frey U, et al. Dynamics of the nasal microbiota in infancy: a prospective cohort study. J Allergy Clin Immunol 2015;135:905-12.e11.

13. Yan M, Pamp SJ, Fukuyama J, Hwang PH, Cho DY, Holmes S, et al. Nasal microenvironments and interspecific interactions influence nasal microbiota complexity and S. aureus carriage. Cell Host Microbe 2013; 14:631-40.

14. García-Rodríguez JA, Fresnadillo Martínez MJ. Dynamics of nasopharyngeal colonization by potential respiratory pathogens. J Antimicrob Chemother 2002;50 Suppl S2:59-73.

15. Faden H, Duffy L, Wasielewski R, Wolf J, Krystofik D, Tung Y. Relationship between nasopharyngeal colonization and the development of otitis media in children. Tonawanda/Williamsville Pediatrics. J Infect Dis 1997; 175:1440-5.

16. Faden H, Waz MJ, Bernstein JM, Brodsky L, Stanievich J, Ogra PL. Nasopharyngeal flora in the first three years of life in normal and otitisprone children. Ann Otol Rhinol Laryngol 1991;100:612-5.

17. Hare KM, Singleton RJ, Grimwood K, Valery PC, Cheng AC, Morris PS, et al. Longitudinal nasopharyngeal carriage and antibiotic resistance of respiratory bacteria in indigenous Australian and Alaska native children with bronchiectasis. PLoS One 2013;8:e70478.

18. Pasare C, Medzhitov R. Toll-like receptors: linking innate and adaptive immunity. Adv Exp Med Biol 2005;560:11-8.

19. Jacoby P, Watson K, Bowman J, Taylor A, Riley TV, Smith DW, et al. Modelling the co-occurrence of Streptococcus pneumoniae with other bacterial and viral pathogens in the upper respiratory tract. Vaccine 2007;25:2458-64.

20. Kao JY, Zhang M, Miller MJ, Mills JC, Wang B, Liu M, et al. Helicobacter pylori immune escape is mediated by dendritic cell-induced Treg skewing and Th17 suppression in mice. Gastroenterology 2010;138:1046-54.

21. Gisselsson-Solén M, Hermansson A, Melhus A, Brodszki N. Immunologic findings in young children with early onset of acute otitis media. Acta Otolaryngol 2014;134:1022-8.

22. Browne JJ, Matthews EH, Taylor-Robinson AW, Kyd JM. Regulatory T lymphocytes are associated with increased nasopharyngeal colonization in children. Int J Pediatr Otorhinolaryngol 2019;120:51-7.

23. Guiducci C, Valzasina B, Dislich H, Colombo MP. CD40/CD40L interaction regulates $\mathrm{CD} 4+\mathrm{CD} 25+\mathrm{T}$ reg homeostasis through dendritic cell-produced IL-2. Eur J Immunol 2005;35:557-67.

24. Meiler F, Zumkehr J, Klunker S, Rückert B, Akdis CA, Akdis M. In vivo switch to IL-10-secreting T regulatory cells in high dose allergen exposure. JExp Med 2008;205:2887-98.

25. Lee KH, Gordon A, Foxman B. The role of respiratory viruses in the etiology of bacterial pneumonia: an ecological perspective. Evol Med Public Health 2016;2016:95-109.

26. DE Lastours V, Malosh R, Ramadugu K, Srinivasan U, Dawid S, Ohmit S, et al. Co-colonization by Streptococcus pneumoniae and Staphylococcus aureus in the throat during acute respiratory illnesses. Epidemiol Infect 2016;144:3507-19.

27. Wen Z, Xie G, Zhou Q, Qiu C, Li J, Hu Q, et al. Distinct nasopharyngeal and oropharyngeal microbiota of children with influenza a virus compared with healthy children. Biomed Res Int 2018;2018:6362716.

28. Fan RR, Howard LM, Griffin MR, Edwards KM, Zhu Y, Williams JV, et al. Nasopharyngeal pneumococcal density and evolution of acute respiratory illnesses in young children, Peru, 2009-2011. Emerg Infect Dis 2016;22:1996-9.

29. Rosas-Salazar C, Shilts MH, Tovchigrechko A, Schobel S, Chappell JD, Larkin EK, et al. Differences in the nasopharyngeal microbiome during acute respiratory tract infection with human rhinovirus and respiratory syncytial virus in infancy. J Infect Dis 2016;214:1924-8.

30. Toivonen L, Camargo CA Jr, Gern JE, Bochkov YA, Mansbach JM, Piedra $\mathrm{PA}$, et al. Association between rhinovirus species and nasopharyngeal microbiota in infants with severe bronchiolitis. J Allergy Clin Immunol 2019;143:1925-8.e7.

31. Mansbach JM, Hasegawa K, Piedra PA, Avadhanula V, Petrosino JF, Sullivan AF, et al. Haemophilus-dominant nasopharyngeal microbiota is associated with delayed clearance of respiratory syncytial virus in infants hospitalized for bronchiolitis. J Infect Dis 2019;219:1804-8.

32. von Linstow ML, Schønning K, Hoegh AM, Sevelsted A, Vissing NH, Bisgaard H. Neonatal airway colonization is associated with troublesome lung symptoms in infants. Am J Respir Crit Care Med 2013;188:1041-2.

33. Bisgaard H, Hermansen MN, Buchvald F, Loland L, Halkjaer LB, Bønnelykke K, et al. Childhood asthma after bacterial colonization of the airway in neonates. NEngl J Med 2007;357:1487-95.

34. Harrison LM, Morris JA, Telford DR, Brown SM, Jones K. The nasopharyngeal bacterial flora in infancy: effects of age, gender, season, viral upper respiratory tract infection and sleeping position. FEMS Immunol Med Microbiol 1999;25:19-28.

35. Syrjänen RK, Auranen KJ, Leino TM, Kilpi TM, Mäkelä PH. Pneumococcal acute otitis media in relation to pneumococcal nasopharyngeal carriage. Pediatr Infect Dis J 2005;24:801-6.

36. Revai K, Mamidi D, Chonmaitree T. Association of nasopharyngeal bacterial colonization during upper respiratory tract infection and the development of acute otitis media. Clin Infect Dis 2008;46:e34-7.

37. Minovi A, Dazert S. Diseases of the middle ear in childhood. GMS Curr Top Otorhinolaryngol Head Neck Surg 2014;13:Doc11.

38. Jervis-Bardy J, Rogers GB, Morris PS, Smith-Vaughan HC, Nosworthy 
E, Leong LE, et al. The microbiome of otitis media with effusion in Indigenous Australian children. Int J Pediatr Otorhinolaryngol 2015;79: 1548-55.

39. Leskinen K, Hendolin P, Virolainen-Julkunen A, Ylikoski J, Jero J. The clinical role of Alloiococcus otitidis in otitis media with effusion. Int J Pediatr Otorhinolaryngol 2002;66:41-8.

40. Güvenç MG, Midilli K, Inci E, Kuşkucu M, Tahamiler R, Ozergil E, et al. Lack of Chlamydophila pneumoniae and predominance of Alloiococcus otitidis in middle ear fluids of children with otitis media with effusion. Auris Nasus Larynx 2010;37:269-73.

41. Marsh RL, Binks MJ, Beissbarth J, Christensen P, Morris PS, Leach AJ, et al. Quantitative PCR of ear discharge from Indigenous Australian children with acute otitis media with perforation supports a role for Alloiococcus otitidis as a secondary pathogen. BMC Ear Nose Throat Disord 2012;12:11.

42. Chan CL, Wabnitz D, Bardy JJ, Bassiouni A, Wormald PJ, Vreugde S, et al. The microbiome of otitis media with effusion. Laryngoscope 2016; 126:2844-51.

43. Stapleton AL, Shaffer AD, Morris A, Li K, Fitch A, Methé BA. The microbiome of pediatric patients with chronic rhinosinusitis. Int Forum Allergy Rhinol 2021;11:31-9.

44. Bassis CM, Tang AL, Young VB, Pynnonen MA. The nasal cavity microbiota of healthy adults. Microbiome 2014;2:27.

45. Drago L, Pignataro L, Torretta S. Microbiological aspects of acute and chronic pediatric rhinosinusitis. J Clin Med 2019;8:149.

46. Hall-Stoodley L, Costerton JW, Stoodley P. Bacterial biofilms: from the natural environment to infectious diseases. Nat Rev Microbiol 2004;2:95-108.

47. Brook I. The role of bacterial interference in otitis, sinusitis and tonsillitis. Otolaryngol Head Neck Surg 2005;133:139-46.

48. Wood AJ, Fraser JD, Swift S, Patterson-Emanuelson EA, Amirapu S, Douglas RG. Intramucosal bacterial microcolonies exist in chronic rhinosinusitis without inducing a local immune response. Am J Rhinol Allergy 2012;26:265-70.

49. Peerbooms PG, Engelen MN, Stokman DA, van Benthem BH, van Weert ML, Bruisten SM, et al. Nasopharyngeal carriage of potential bacterial pathogens related to day care attendance, with special reference to the molecular epidemiology of Haemophilus influenzae. J Clin Microbiol 2002;40:2832-6

50. Simell B, Auranen K, Käyhty H, Goldblatt D, Dagan R, O'Brien KL, et al. The fundamental link between pneumococcal carriage and disease. Expert Rev Vaccines 2012;11:841-55.

51. McDaniel LS, Swiatlo E. Should pneumococcal vaccines eliminate nasopharyngeal colonization? mBio 2016;7:e00545-16.

52. Lee EK, Jun JK, Choi UY, Kwon HJ, Kim KH, Kang JH. Nasopharyngeal carriage rate and serotypes of streptococcus pneumoniae and antimicrobial susceptibility in healthy Korean children younger than 5 years old: focus on influence of pneumococcal conjugate vaccination. Infect Chemother 2013;45:76-84.

53. Choe YJ, Lee HJ, Lee H, Oh CE, Cho EY, Choi JH, et al. Emergence of antibiotic-resistant non-vaccine serotype pneumococci in nasopharyngeal carriage in children after the use of extended-valency pneumococcal conjugate vaccines in Korea. Vaccine 2016;34:4771-6.

54. Cho EY, Choi EH, Kang JH, Kim KH, Kim DS, Kim YJ, et al. Early changes in the serotype distribution of invasive pneumococcal isolates from children after the introduction of extended-valent pneumococcal conjugate vaccines in Korea, 2011-2013. J Korean Med Sci 2016;31: $1082-8$.

55. Lee J, Kim KH, Jo DS, Ma SH, Kim JH, Kim CS, et al. A longitudinal hospital-based epidemiology study to assess acute otitis media incidence and nasopharyngeal carriage in Korean children up to 24 months. Hum Vaccin Immunother 2020;16:3090-7.

56. Syrjänen RK, Herva EE, Mäkelä PH, Puhakka HJ, Auranen KJ, Takala $\mathrm{AK}$, et al. The value of nasopharyngeal culture in predicting the etiology of acute otitis media in children less than two years of age. Pediatr Infect Dis J 2006;25:1032-6.

57. Xu Q, Casey JR, Chang A, Pichichero ME. When co-colonizing the nasopharynx haemophilus influenzae predominates over Streptococcus pneumoniae except serotype 19A strains to cause acute otitis media. Pediatr Infect Dis J 2012;31:638-40.

58. Siegel SJ, Weiser JN. Mechanisms of bacterial colonization of the respiratory tract. Annu Rev Microbiol 2015;69:425-44.

59. Wolter N, Tempia S, Cohen C, Madhi SA, Venter M, Moyes J, et al. High nasopharyngeal pneumococcal density, increased by viral coinfection, is associated with invasive pneumococcal pneumonia. J Infect Dis 2014;210:1649-57.

60. Short KR, Habets MN, Hermans PW, Diavatopoulos DA. Interactions between Streptococcus pneumoniae and influenza virus: a mutually beneficial relationship? Future Microbiol 2012;7:609-24.

61. Hanage WP, Auranen K, Syrjänen R, Herva E, Mäkelä PH, Kilpi T, et al. Ability of pneumococcal serotypes and clones to cause acute otitis media: implications for the prevention of otitis media by conjugate vaccines. Infect Immun 2004;72:76-81.

62. Shouval DS, Greenberg D, Givon-Lavi N, Porat N, Dagan R. Site-specific disease potential of individual Streptococcus pneumoniae serotypes in pediatric invasive disease, acute otitis media and acute conjunctivitis. Pediatr Infect Dis J 2006;25:602-7.

63. Pelton SI. Deconstructing pneumococcal progression from colonization to disease. Infect Immun 2018;86:e00225-18.

64. Lal D, Keim P, Delisle J, Barker B, Rank MA, Chia N, et al. Mapping and comparing bacterial microbiota in the sinonasal cavity of healthy, allergic rhinitis, and chronic rhinosinusitis subjects. Int Forum Allergy Rhinol 2017;7:561-9.

65. Teo SM, Mok D, Pham K, Kusel M, Serralha M, Troy N, et al. The infant nasopharyngeal microbiome impacts severity of lower respiratory infection and risk of asthma development. Cell Host Microbe 2015;17: 704-15.

66. Choi CH, Poroyko V, Watanabe S, Jiang D, Lane J, deTineo M, et al. Seasonal allergic rhinitis affects sinonasal microbiota. Am J Rhinol Allergy 2014;28:281-6.

67. Chung KF. Potential role of the lung microbiome in shaping asthma phenotypes. Ann Am Thorac Soc 2017;14(Supplement_5):S326-31.

68. Pérez-Losada M, Crandall KA, Freishtat RJ. Two sampling methods yield distinct microbial signatures in the nasopharynges of asthmatic children. Microbiome 2016;4:25.

69. Pérez-Losada M, Alamri L, Crandall KA, Freishtat RJ. Nasopharyngeal microbiome diversity changes over time in children with asthma. PLoS One 2017;12:e170543.

70. Pérez-Losada M, Authelet KJ, Hoptay CE, Kwak C, Crandall KA, Freishtat RJ. Pediatric asthma comprises different phenotypic clusters with unique nasal microbiotas. Microbiome 2018;6:179.

71. Vissing NH, Chawes BL, Bisgaard H. Increased risk of pneumonia and bronchiolitis after bacterial colonization of the airways as neonates. Am J Respir Crit Care Med 2013;188:1246-52.

72. Rubin K, Glazer S. The pertussis hypothesis: bordetella pertussis colonization in the etiology of asthma and diseases of allergic sensitization. Med Hypotheses 2018;120:101-15.

73. Fazlollahi M, Lee TD, Andrade J, Oguntuyo K, Chun Y, Grishina G, et al. The nasal microbiome in asthma. J Allergy Clin Immunol 2018;142:83443.e2.

74. Ishida Y, Nakamura F, Kanzato H, Sawada D, Hirata H, Nishimura A, et al. Clinical effects of Lactobacillus acidophilus strain L-92 on perennial allergic rhinitis: a double-blind, placebo-controlled study. J Dairy Sci 2005;88:527-33.

75. Lin WY, Fu LS, Lin HK, Shen CY, Chen YJ. Evaluation of the effect of Lactobacillus paracasei (HF.A00232) in children (6-13 years old) with perennial allergic rhinitis: a 12-week, double-blind, randomized, placebocontrolled study. Pediatr Neonatol 2014;55:181-8.

76. Jerzynska J, Stelmach W, Balcerak J, Woicka-Kolejwa K, Rychlik B, Blauz A, et al. Effect of Lactobacillus rhamnosus GG and vitamin D supplementation on the immunologic effectiveness of grass-specific sublingual immunotherapy in children with allergy. Allergy Asthma Proc 2016;37:324-34.

77. Luoto R, Ruuskanen O, Waris M, Kalliomäki M, Salminen S, Isolauri E. 
Prebiotic and probiotic supplementation prevents rhinovirus infections in preterm infants: a randomized, placebo-controlled trial. J Allergy Clin Immunol 2014;133:405-13.

78. Panigrahi P, Parida S, Nanda NC, Satpathy R, Pradhan L, Chandel DS, et al. A randomized synbiotic trial to prevent sepsis among infants in rural India. Nature 2017;548:407-12.

79. De Grandi R, Drago L, Bidossi A, Bottagisio M, Gelardi M, De Vecchi E. Putative microbial population shifts attributable to nasal administration of Streptococcus salivarius 24SMBc and Streptococcus oralis 89a. Probiotics Antimicrob Proteins 2019;11:1219-26.

80. Yang Y, Jing Y, Yang J, Yang Q. Effects of intranasal administration with Bacillus subtilis on immune cells in the nasal mucosa and tonsils of piglets. Exp Ther Med 2018;15:5189-98.

81. Kumpitsch C, Koskinen K, Schöpf V, Moissl-Eichinger C. The microbiome of the upper respiratory tract in health and disease. BMC Biol 2019;17:87.

82. de Steenhuijsen Piters WA, Sanders EA, Bogaert D. The role of the local microbial ecosystem in respiratory health and disease. Philos Trans R Soc Lond B Biol Sci 2015;370:20140294.

83. Biesbroek G, Tsivtsivadze E, Sanders EA, Montijn R, Veenhoven RH, Keijser BJ, et al. Early respiratory microbiota composition determines bacterial succession patterns and respiratory health in children. Am J Respir Crit Care Med 2014;190:1283-92.

84. Biesbroek G, Bosch AA, Wang X, Keijser BJ, Veenhoven RH, Sanders $\mathrm{EA}$, et al. The impact of breastfeeding on nasopharyngeal microbial communities in infants. Am J Respir Crit Care Med 2014;190:298-308.

85. Shilts MH, Rosas-Salazar C, Tovchigrechko A, Larkin EK, Torralba M, Akopov A, et al. Minimally invasive sampling method identifies differences in taxonomic richness of nasal microbiomes in young infants associated with mode of delivery. Microb Ecol 2016;71:233-42.

86. Frayman KB, Armstrong DS, Grimwood K, Ranganathan SC. The airway microbiota in early cystic fibrosis lung disease. Pediatr Pulmonol 2017;52:1384-404.

87. Dumas A, Bernard L, Poquet Y, Lugo-Villarino G, Neyrolles O. The role of the lung microbiota and the gut-lung axis in respiratory infectious diseases. Cell Microbiol 2018;20:e12966.

88. Schenck LP, Surette MG, Bowdish DM. Composition and immunological significance of the upper respiratory tract microbiota. FEBS Lett 2016;590:3705-20.

89. Prevaes SM, de Winter-de Groot KM, Janssens HM, de Steenhuijsen Piters WA, Tramper-Stranders GA, Wyllie AL, et al. Development of the nasopharyngeal microbiota in infants with cystic fibrosis. Am J Respir Crit Care Med 2016;193:504-15.

90. Luna PN, Hasegawa K, Ajami NJ, Espinola JA, Henke DM, Petrosino JF, et al. The association between anterior nares and nasopharyngeal microbiota in infants hospitalized for bronchiolitis. Microbiome 2018;6:2.

91. Moore HC, Jacoby P, Taylor A, Harnett G, Bowman J, Riley TV, et al. The interaction between respiratory viruses and pathogenic bacteria in the upper respiratory tract of asymptomatic aboriginal and non-aboriginal children. Pediatr Infect Dis J 2010;29:540-5.
92. van den Bergh MR, Biesbroek G, Rossen JW, de Steenhuijsen Piters WA, Bosch AA, van Gils EJ, et al. Associations between pathogens in the upper respiratory tract of young children: interplay between viruses and bacteria. PLoS One 2012; 7:e47711.

93. Chertow DS, Memoli MJ. Bacterial coinfection in influenza: a grand rounds review. JAMA 2013;309:275-82.

94. Ichinohe T, Pang IK, Kumamoto Y, Peaper DR, Ho JH, Murray TS, et al. Microbiota regulates immune defense against respiratory tract influenza A virus infection. Proc Natl Acad Sci US A 2011;108:5354-9.

95. Borges LGDA, Giongo A, Pereira LM, Trindade FJ, Gregianini TS, Campos FS, et al. Comparison of the nasopharynx microbiome between influenza and non-influenza cases of severe acute respiratory infections: a pilot study. Health Sci Rep 2018;1:e47.

96. Laufer AS, Metlay JP, Gent JF, Fennie KP, Kong Y, Pettigrew MM. Microbial communities of the upper respiratory tract and otitis media in children. mBio 2011;2:e00245-10.

97. Lappan R, Imbrogno K, Sikazwe C, Anderson D, Mok D, Coates H, et al. A microbiome case-control study of recurrent acute otitis media identified potentially protective bacterial genera. BMC Microbiol 2018; $18: 13$.

98. Chonmaitree T, Jennings K, Golovko G, Khanipov K, Pimenova M, Patel JA, et al. Nasopharyngeal microbiota in infants and changes during viral upper respiratory tract infection and acute otitis media. PLoS One 2017;12:e0180630.

99. Bhattacharyya N, Kepnes LJ. Assessment of trends in antimicrobial resistance in chronic rhinosinusitis. Ann Otol Rhinol Laryngol 2008; 117:448-52.

100. Kingdom TT, Swain RE Jr. The microbiology and antimicrobial resistance patterns in chronic rhinosinusitis. Am J Otolaryngol 2004;25:323-8.

101.Coffey CS, Sonnenburg RE, Melroy CT, Dubin MG, Senior BA. Endoscopically guided aerobic cultures in postsurgical patients with chronic rhinosinusitis. Am J Rhinol 2006;20:72-6.

102.Mårtensson A, Abolhalaj M, Lindstedt M, Mårtensson A, Olofsson TC, Vásquez A, et al. Clinical efficacy of a topical lactic acid bacterial microbiome in chronic rhinosinusitis: a randomized controlled trial. Laryngoscope Investig Otolaryngol 2017;2:410-6.

103. Kiryukhina NV, Melnikov VG, Suvorov AV, Morozova YA, Ilyin VK. Use of Corynebacterium pseudodiphtheriticum for elimination of Staphylococcus aureus from the nasal cavity in volunteers exposed to abnormal microclimate and altered gaseous environment. Probiotics Antimicrob Proteins 2013;5:233-8.

104.Mukerji SS, Pynnonen MA, Kim HM, Singer A, Tabor M, Terrell JE. Probiotics as adjunctive treatment for chronic rhinosinusitis: a randomized controlled trial. Otolaryngol Head Neck Surg 2009;140:202-8.

How to cite this article: Kang HM, Kang JH. Effects of nasopharyngeal microbiota in respiratory infections and allergies Clin Exp Pediatr 2021;63:543-51. https://doi.org/10.3345/cep. 2020.01452 